\title{
UNDERGROUND WATER QUALITY OF ROCK MINING IN ISHIAGU, EBONYI STATE, NIGERIA
}

\author{
Qualidade da Água da Mina de Crushrock em Ishiagu, \\ Estado de Ebonyi, Nigéria
}

Obiekezie, SO. ${ }^{1}$

Okereke, JN. ${ }^{1}$

Anyalogbu, E. ${ }^{1}$

Okorondu S.I

Ezejiofor, TIN. ${ }^{1}$

\begin{abstract}
Physicochemical and bacteriological analysis of underground water of Crush Rock mining pit in Ishiagu, Ebonyi State Nigeria were carried out to determined the pollution level and the potability of the groundwater due to mining and human activities. The results were compared with standards for water pollution and World Health Organization for drinking water. The results showed that total dissolved solids (TDS), total alkalinity, calcium and sodium, which had concentration ranges of 126-986ppm, 200.18-615.55ppm, 7.830.10ppm and 64-88ppm respectively, were above standards. However, the mean concentration of dissolved oxygen (DO) (1.2-3.20ppm) was below the standard. Other parameters measured were found to be within the permissible acceptable standard. Pseudomonas, Chromobacterium, Bacillus, Escherichia, Staphylococcus, Flavobacterium, Micrococcus, Citrobacter and Achromobacter species were identified as the major bacteria isolated from the underground water. The study revealed that the underground water from Crush Rock mining pit in Ishiagu Ebonyi State, Nigeria require some chemical and physical treatment as it is unsafe for human consumption.
\end{abstract}

Keywords: Underground water; Potability; Pollution; Bacteria.

\footnotetext{
Department of Biotechnology, Federal University of Technology Owerri, Imo State, Nigeria

Department of Microbiology, Federal University of Technology Imo State, Nigeria. Corresponding Author: Dr. S.O. Obiekezie Email: drsmartobiekezie@yahoo.com
} 


\section{Resumo}

Análises fisico-químicas e bacteriológicas da água da mina de Crush Rock em Ishiagu, estado de Ebonyi, na Nigéria, foram feitas para determinar o nível de poluição e potabilidade da água subterrânea, devido à mineração e às atividades humanas. Os resultados foram comparados com os padrões da Organização Mundial da Saúde. Os resultados mostraram que o total de sólidos dissolvidos (TSD), alcalinidade total, cálcio e sódio tinham concentrações variando, respectivamente, entre 126 a 986 ppm, 200,18 a 615,55ppm, 7,8 a 30,10 ppm e 64 a 88 ppm estiveram acima dos padrões. Entretanto, a concentração média de oxigênio dissolvido (OD) variava entre 1,2 a 3,2 ppm, abaixo do padrão. Outros parâmetros medidos foram encontrados dentro do aceitável permitido. Pseudomonas, Chromobacterium, Bacillus, Escherichia, Staphylococcus, Flavobacterium, Micrococcus, Citrobacter e Achromobacter foram identificadas como as principais espécies de bactérias isoladas da água. O estudo revelou que a água da mina de Crush Rock requer tratamento químico e físico, para poder ser consumida pela população, já que nas condições atuais ela não é potável. Palavras-chave: Água subterrânea; Potabilidade; Poluição; Bactérias.

\section{Introduction}

Underground water is a body of water occurring in the subsurface especially in the zone of saturation where all the pores and cracks are filled with water. During the percolation of groundwater, it takes along dissolved organic and inorganic materials. Microorganisms are frequently trapped on the surface water and as the water percolates some of the microorganisms will find their ways into the groundwater.

Global industrialization, Africa inclusive, has resulted in increased demand for this natural resources, water and this is more severe in the third world countries like Nigeria. The discharge of untreated or fairly treated wastes into ecosystems brings about structural, physical and chemical changes which often affect the biota (1) The physicochemical attributes of any water body are prime factors which influence its overall productivity, reproduction, and growth performance (2). Of notable importance are $\mathrm{pH}$, transparency, temperature, dissolved oxygen, suspended solids, biochemical oxygen demand and dissolved ions, of which, play critical role in determining the suitability of the water for aquatic life as well as for other human uses (3). Any alteration of these water parameters, either through anthropogenic activities or natural disaster, often results in concomitant alteration of the aquatic life. WHO (4) described water not only as a giver of life but also as a source of many human diseases. The status of biological communities, particularly bacteriological quality, in water is of direct interest to microbiologists, hydrobiologists, public health officers, town planners, statisticians, engineers etc., as it serves as a measure of the extent of pollution in the system.
Monitoring the pollution level of water bodies in the developed world has been a continuous process $(5,6,7)$, but the pollution level of Nigeria's water has not been adequately monitored. The scourge of water and soil pollution on our people cannot be over emphasized and had made studies directed towards such investigations to be of utmost importance in alleviating the accompanying undesirable impact on the populace. Furthermore, the awareness such studies would create would be invaluable to our national government and other international organization in the realization of a healthy populace. This is of utmost importance and interest, especially now that there is global call on governments to give priority attention to environmental protection efforts in their countries $(4,68)$.

Following the various industrial (especially rock mining), agricultural and commercial activities taking place in Ebonyi State, South-East Nigeria, this work is aimed at evaluating the effects of crush rock in Ebonyi State Nigeria.

\section{Materials and Methods}

Three sampling points were selected which were made up of one from the center and two from the banks. One and half liter of polythene containers with screw stoppers were used for collection of the samples. The containers were thoroughly washed with detergent after soaking them overnight and finally they were rinsed with deionised water. At the sampling point, each labeled container was rinsed with the sample. The sample was collected by stirring the 'spot and the container 
Underground water quality of rock mining in Ishiagu, Ebonyi state, Nigeria

was lowered to about $15 \mathrm{~cm}$ depth to collect representative water sample. The samples were transported to the laboratory within 2-4 hours and stored at $40^{\circ} \mathrm{C}$ prior to analysis.

The temperature of the water was determined with a digital mercury thermometer and the turbidity of the water sample was determined with turbidimeter (9). Conductivity was determined by the method in Philips manual of laboratory conductivity meter (1O). Total dissolved solid (TDS) was indirectly determined using the equation: TDS = Conductivity / 2 (11). The total suspended solids (TSS) were determined by calling up the program number (20) for total suspended solids on the Shimadzu UV - 160A-recording spectrophotometer at $400 \mathrm{~nm}$. Following standardization with distilled water as blank, the samples were then introduced and the values read off as displayed on the screen (11). The $\mathrm{pH}$ was determined using Corning digital 112-pH meter.

Sulphate, chloride, sodium, potassium, alkalinity, silica, and dissolved oxygen content were determined by the methods outlined in standard methods for examination of Water and Waste Water (12). Calcium ion (hardness) was estimated by application of the method report in Hachwater Analysis Hand Book $(11,13)$.

The trace / heavy metals $(\mathrm{Pb}, \mathrm{Zn}, \mathrm{Fe}, \mathrm{Cd}$ and $\mathrm{Cu}$ ) content were assayed with Atomic Absorption Spectrophotometer, Unican 969 in an air-acetylene flame.

Bacteriological investigation was carried out by pour plate method on a nutrient agar which was prepared according to the manufacturer's instruction, and was sterilized in the autoclave at $121^{\circ}$ for $15 \mathrm{~min}$. one milliliter of each water sample was transferred with sterile pipette into sterile petri dishes. The agar was poured into each of the petri dishes. The petri-dishes were rocked gently to mix the agar and the water sample. The plate was later incubated at $37^{\circ} \mathrm{C}$ for $24-48$ hours for bacteria. At the end of the incubation, the colonies that developed in plates were counted with colony counter. The isolates were further characterized and identified by carrying out Grem staining, catalase, citrate, oxidase and some other biochemical tests.

\section{Results}

Table I summarized the physical properties of underground water of crush mining while tables II and III present chemical properties and the heavy metal values of the groundwater respectively. The seasonal variation of physicochemical qualities of the underground water is presented in table IV . The Results show that $\mathrm{pH}$ of the water sample lies between 7.5 and 8.2, and temperature was in the range of $26.1-27.1^{\circ} \mathrm{C}$ while turbidity, conductivity, total suspended solid (TSS), total dissolved (TDS) and dissolved oxygen had ranges of 0.5-179.4 \{NTD\}, 253-1800 ppm, 4.01-26.4 ppm, 126-986 ppm, and 1.2-3.20 ppm respectively. Similarly, the range of potassium (0.03-0.57 ppm), calcium (7.8-30.10 ppm), silica (2.120-3.590 ppm), sulphate (37.80-115.00 ppm), chloride (42.76.21 ppm), sodium (64.88 ppm) and alkalinity (200.18$615.55 \mathrm{ppm}$ ). The heavy metal contamination was low as their values ranged from 0-0.062 ppm from iron, 0-0.042 ppm for lead, 0-0.014 ppm for cadmium, 0-0.005 ppm and 0.009 for copper.

Table $\mathrm{V}$ showed that bacteria species made up of Gram positive and Gram negative organisms were isolated from the underground water. They included Pseudomonas, Chromobacterium, Bacillus, Escherichia, and Staphylococcus species. Others were Flavobacterium, Micrococcus, Citrobacter and Achromobacter species. The prevalence of bacterial organisms isolated was presented in table IV. Pseudomas and Bacillus species had the highest prevalence of $100 \%$ occurring in all the samples screened, and Escherichia coli and Chromobacterium species had prevalence of 91.6\% and $66.6 \%$ respectively. This was followed by Staphylococus species (50\%), Flavobacterium species (41.7\%), Micrococcus and Achromobacter species had 33.3\% each, while the least prevalent organism was Citrobacter species with 25\% occurrence. 


\section{TABLE I: Physical properties of underground water of Crush Rock Mining}

\begin{tabular}{|c|c|c|c|c|c|c|}
\hline Date & Temp. ${ }^{\circ} \mathrm{C}$ & Turbidity (NTU) & Conductivity (ms/cm) & TDS (ppm) & TSS (ppm) & $\mathbf{P H}$ \\
\hline Aug. 2002 & 28.0 & 179.4 & 250 & 126 & 4 & 8.1 \\
\hline Oct. 2002 & 27.4 & 150.1 & 1871 & 986 & 26.41 & 7.6 \\
\hline Dec. 2002 & 27.6 & 0.5 & 1650 & 814 & 18.32 & 7.7 \\
\hline Feb. 2003 & 27.6 & 19.2 & 1224 & 688 & 9.1 & 7.6 \\
\hline Apr. 2003 & 28.6 & 4.4 & 629 & 339 & 8.06 & 7.6 \\
\hline Jun. 2003 & 28.3 & 2.1 & 359 & 186 & 46.2 & 7.6 \\
\hline Aug. 2003 & 28.0 & 17.9 & 253 & 126 & 4.01 & 8.2 \\
\hline Oct. 2003 & 27.6 & 14.7 & 390 & 148 & 15.01 & 7.6 \\
\hline Dec. 2003 & 27.4 & 1.0 & 1453 & 718 & 9.26 & 7.5 \\
\hline Feb. 2004 & 27.5 & 19.0 & 860 & 480 & 9.01 & 7.7 \\
\hline Apr. 2004 & 26.1 & 4.4 & 609 & 301 & 8.0 & 7.6 \\
\hline Jun. 2004 & 26.8 & 2.1 & 360 & 181 & 4.61 & 7.6 \\
\hline
\end{tabular}

TABLE II: Chemical properties of underground water of Crush Rock Mining

\begin{tabular}{|c|c|c|c|c|c|c|c|c|}
\hline Date & $\begin{array}{l}\mathrm{SO}_{4}{ }^{2+} \\
(\mathrm{ppm})\end{array}$ & $\begin{array}{l}\text { CL } \\
\text { (ppm) }\end{array}$ & $\begin{array}{l}\mathrm{Na}^{+} \\
(\mathrm{ppm})\end{array}$ & $\begin{array}{l}\text { Alkalinity } \\
\text { (ppm) }\end{array}$ & $\begin{array}{l}\mathrm{K}^{+} \\
\text {(ppm) }\end{array}$ & $\begin{array}{l}\mathrm{Ca}^{2+} \\
(\mathrm{ppm})\end{array}$ & $\begin{array}{l}\text { Silica } \\
\text { (ppm) }\end{array}$ & $\begin{array}{l}\text { DO } \\
\text { (ppm) }\end{array}$ \\
\hline Aug. 2002 & 100.0 & 42.1 & 65 & 200.2 & 0.03 & 14.2 & 3.69 & 1.2 \\
\hline Oct. 2002 & 50.4 & 50.61 & 88 & 200.2 & 0.18 & 10.6 & 2.12 & 1.8 \\
\hline Dec. 2002 & 90.4 & 47.1 & 84 & 350.5 & 0.16 & 7.8 & 2.54 & 2.0 \\
\hline Feb. 2003 & 37.8 & 47.1 & 85 & 615.6 & 0.57 & 20.2 & 3.02 & 3.2 \\
\hline Apr. 2003 & 680 & 45.6 & 70 & 260.4 & 0.21 & 30.1 & 2.91 & 1.2 \\
\hline Jun. 2003 & 45.3 & 42.8 & 64 & 201.6 & 0.01 & 9.0 & 2.55 & 1.6 \\
\hline Aug. 2003 & 115.2 & 43.1 & 66 & 240.7 & 0.003 & 12.2 & 3.59 & 2.0 \\
\hline Oct. 2003 & 60.1 & 50.1 & 82 & 210.2 & 0.15 & 11.8 & 3.01 & 1.6 \\
\hline Dec. 2003 & 64.0 & 56.2 & 84 & 310.1 & 0.22 & 10.0 & 3.14 & 2.0 \\
\hline Feb. 2004 & 45.2 & 54.0 & 82 & 412.6 & 0.46 & 8.14 & 3.26 & 2.2 \\
\hline Apr. 2004 & 70 & 47.6 & 70 & 250.0 & 0.26 & 30.1 & 2.11 & 1.2 \\
\hline Jun. 2004 & 80.2 & 48.7 & 74 & 261.6 & 0.16 & 9.0 & 2.55 & 1.5 \\
\hline
\end{tabular}


TABLE III: Heavy metal values of underground water of Crush Rock

\begin{tabular}{llllll}
\hline Date & Fe (ppm) & Pb $(\mathbf{p p m})$ & Cd (ppm) & Zn (ppm) & Cu (ppm) \\
\hline Aug. 02 & 0.01 & 0.02 & 0.02 & 0 & 0.01 \\
Oct. 02 & 0.02 & 0.01 & 0.01 & 0 & 0.01 \\
Dec. 02 & 0 & 0 & 0 & 0 & 0 \\
Feb. 03 & 0 & 0.04 & 0 & 0.01 & 0.01 \\
Apr. 03 & 0.01 & 0 & 0 & 0 & 0 \\
Jun. 03 & 0.06 & 0.01 & 0 & 0 & 0.01 \\
Aug. 03 & 0.01 & 0.02 & 0.01 & 0 & 0.01 \\
Oct. 03 & 0.02 & 0.01 & 0 & 0 & 0.01 \\
Dec. 03 & 0.01 & 0.01 & 0 & 0 & 0.01 \\
Feb. 04 & 0.01 & 0.01 & 0 & 0 & 0 \\
Apr. 04 & 0.02 & 0 & 0 & 0 & 0 \\
Jun. 04 & 0.06 & 0.01 & 0 & 0 & 0.01 \\
\hline
\end{tabular}

TABLE IV: Seasonal variation of physicochemical qualities of underground water of crush rock mining

\begin{tabular}{|c|c|c|c|c|c|c|}
\hline \multirow[b]{2}{*}{ Parameter } & \multirow[b]{2}{*}{ Mean } & \multicolumn{2}{|c|}{$\begin{array}{l}\text { Dry Season } \\
\mathbf{N}=\mathbf{6}\end{array}$} & \multicolumn{3}{|c|}{$\begin{array}{l}\text { Rainy Season } \\
N=6\end{array}$} \\
\hline & & SD & Range & Mean & SD & T. level \\
\hline $\mathrm{PH}$ & 7.62 & 0.08 & $7.5-8.20$ & 7.8 & 0.35 & -1.465 \\
\hline Temp. & 27.52 & 0.09 & 26.1-27.10 & 26.73 & 0.55 & 2.065 \\
\hline Turbidity & 9.32 & 9.26 & $0.5-179.40$ & 61.97 & 101.71 & -0.817 \\
\hline Conductivity & 1229.5 & 527.93 & $253-1800$ & 413.67 & 291.90 & 0.081 \\
\hline TSS & 14.54 & 6.95 & $4.01-26.40$ & 5.56 & 2.18 & 3.052 \\
\hline TDS & 639.0 & 291.90 & $126-986$ & 217.0 & 109.83 & 3.441 \\
\hline DO & 2.13 & 0.56 & $12-3.20$ & 1.6 & 0.4 & 2.023 \\
\hline Potassium & 0.29 & 0.18 & $0.03-0.57$ & 0.11 & 0.09 & 1.947 \\
\hline Calcium & 11.42 & 4.56 & 7.8-30.10 & 17.1 & 11.37 & -4.490 \\
\hline Silica & 2.84 & 0.44 & $2.120-3.590$ & 3.02 & 0.53 & -0.191 \\
\hline Sulphate & 57.99 & 18.54 & $37.80-115.00$ & 76.17 & 35.66 & -1.723 \\
\hline Cloride & 50.85 & 3.67 & $42.76-56.21$ & 43.82 & 1.55 & 3.135 \\
\hline Sodium & 84.17 & 2.23 & $64-88$ & 66.67 & 3.06 & 8.868 \\
\hline Alkalinity & 349.83 & 153.64 & $200.18-615.55$ & 234.25 & 29.93 & 1.972 \\
\hline Iron & 0.02 & 0.02 & $0.0-0.062$ & 0.03 & 0.03 & -0.679 \\
\hline Lead & 0.01 & 0.01 & $0.0-0.042$ & 0.01 & 0.01 & 1.912 \\
\hline Cadmium & 0.004 & 0.003 & $0.0-0.014$ & 0.006 & 0.007 & 3.627 \\
\hline Zinc & 0.001 & 0.002 & $0.0-0.005$ & 0.001 & 0.002 & 0.0 \\
\hline Copper & 0.006 & 0.003 & $0.0-0.009$ & 0.006 & 0.005 & 0.420 \\
\hline
\end{tabular}




\begin{tabular}{|c|c|c|c|}
\hline 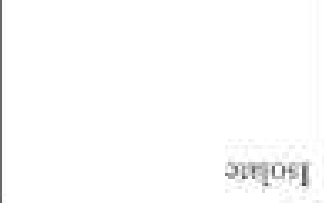 & है & $\frac{E}{6}$ & 售 \\
\hline $250 \hat{x} \mathrm{X}$ & & , & \\
\hline ग60134य & & . & \\
\hline उร०3חD & $<$ & & \\
\hline 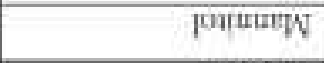 & $<$ & . & , \\
\hline क्रscumes & 1 & . & . \\
\hline अOभाषW & 1 & , & + \\
\hline 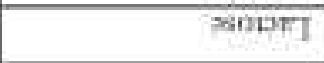 & $<$ & . & i.. \\
\hline sonxpst ment & + & . & i \\
\hline 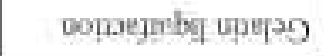 & . & . & + \\
\hline $132 \mathrm{~L} \mathrm{I} / \mathrm{O}$ & \pm & 0 & 0 \\
\hline W & . & , & , \\
\hline SH & i & . & , \\
\hline solisopury & + & . & . \\
\hline IMIDOW & . & . & + \\
\hline 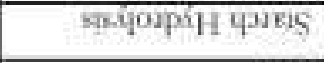 & $i$ & . & + \\
\hline di & + & + & i \\
\hline $\mathrm{d} W$ & i. & . & 1 \\
\hline FSL $.96 \times)$ & + & . & + \\
\hline 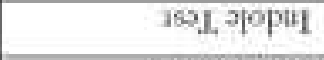 & 1 & . & . \\
\hline 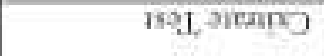 &. & . & + \\
\hline 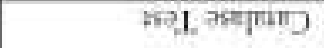 & + & + & . \\
\hline 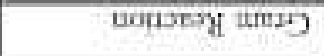 & , & . & . \\
\hline 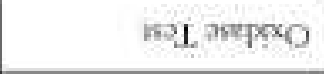 & + & . & + \\
\hline 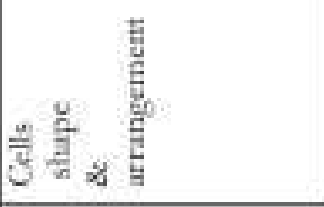 & $\begin{array}{l}5 \\
\frac{5}{2} \\
\frac{1}{2}\end{array}$ & 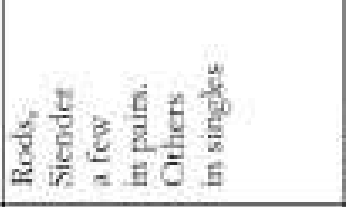 & $\frac{\pi}{8}$ \\
\hline है है है & 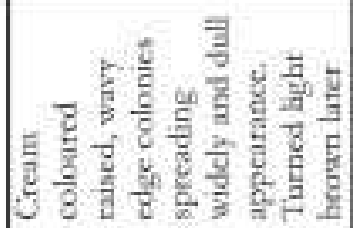 & 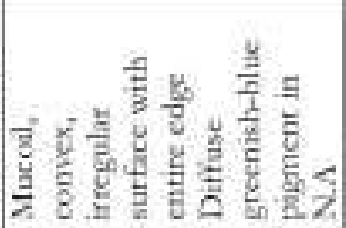 & 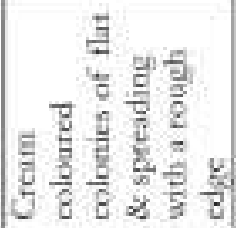 \\
\hline
\end{tabular}




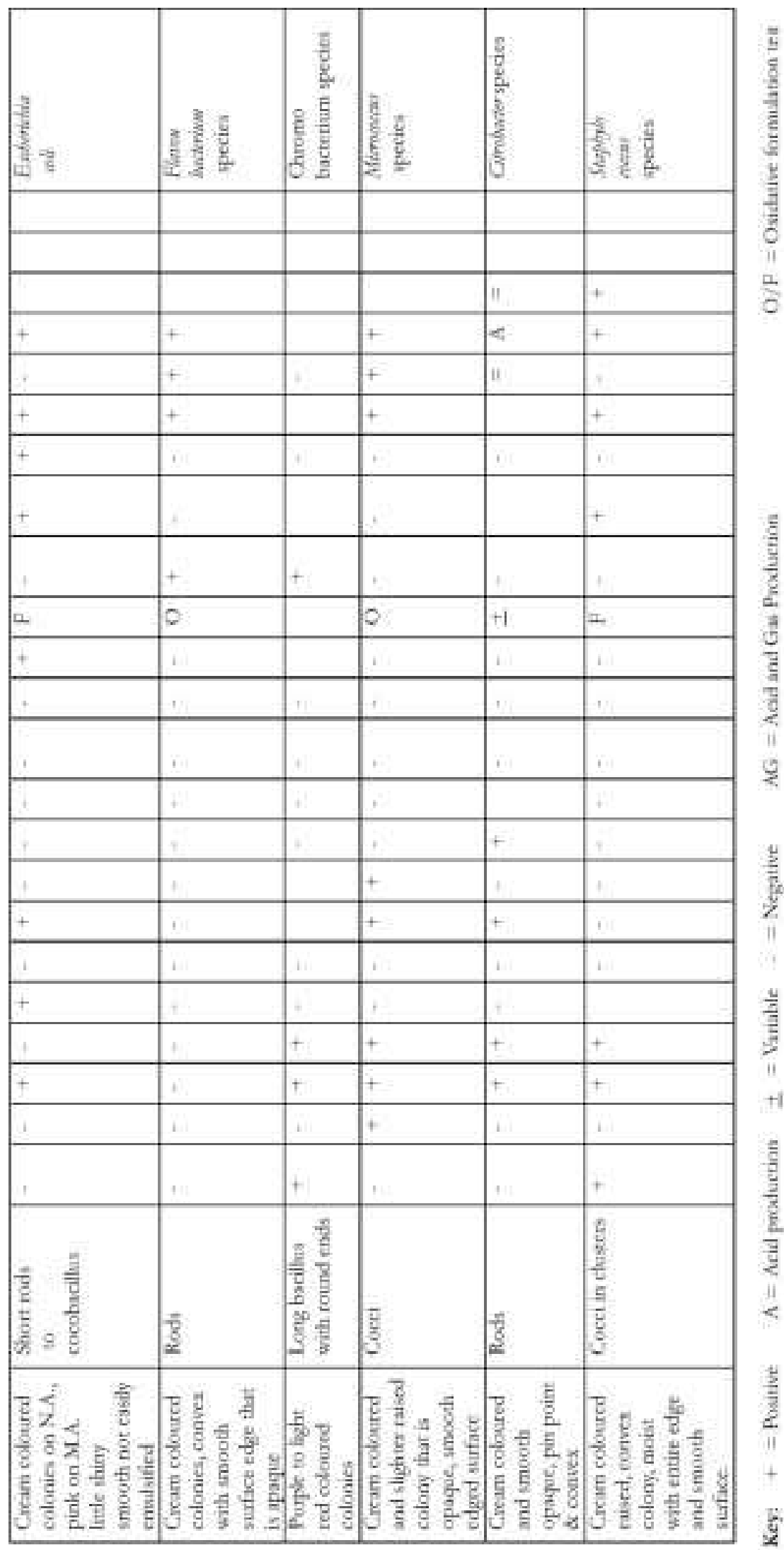




\section{Discussion}

It is difficult to find a river or other body of water whose natural regime has not been modified in one way or another by man's activity. At the same time, man really depends on water for domestic consumption, industrial, recreational and agricultural purpose and the quality of water for each purpose differs tremendously. The result of our study revealed that the mean $\mathrm{pH}$ concentration for dry (7.62) and rainy (7.8) seasons were within the range of 7-8.5 as set by WHO (14) for drinking water. $\mathrm{pH}$ which is bellow 7 can impart a sharp acid taste to water and can easily corrode the pipe borne plumbing (11). The temperature range of $26.1-27.1^{\circ} \mathrm{C}$ falls within the normal international standard for discharge into streams. The mean value of temperature was found to be higher in dry season $\left(27.52^{\circ} \mathrm{C}\right)$ than the rainy season $\left(26.73^{\circ} \mathrm{C}\right)$. The highest temperature values were recorded in the months of April $\left(28.6^{\circ} \mathrm{C}\right)$ and June $\left(28.3^{\circ} \mathrm{C}\right) 2003$ while the least temperature value was in April $\left(26.1^{\circ} \mathrm{C}\right) 2004$. Similar findings were recorded in our earlier work (15). It is important to note that temperature exerts a marked effect upon the pollutional characteristics of a stream or water body since the amount of oxygen that a water body can carry is inversely proportional to the temperature of the water body. The temperature values for the study did not vary much in both seasons. A water body whose temperature rises above $33^{\circ} \mathrm{C}$ is generally considered unsuitable for public water supplies $(16,17,18)$. Turbidity is one of the water characteristics, which although not harmful to the health of people using it but may affect its acceptability as a domestic supply. The international standard sets the maximum permissible level for turbidity at 25 units (19). The results indicated clearly that the rainy season mean turbidity value. (61.97 NTU) was higher than the dry season value (9.32 NTU). That is the rainy season value was above the international standard while the dry season value was below the WHO standard. The implication of the higher values of turbidity is that more energy and chemicals will be needed in rainy season than in the dry season at the treatment plant (16). The conductivity values were highest in the months of October, $2002(1871 \mathrm{~ms} / \mathrm{cm})$ and December 2003 (1453 ms/cm). The least values of $250 \mathrm{~ms} / \mathrm{cm}, 253 \mathrm{~ms} / \mathrm{cm}$, and $359 \mathrm{~ms} / \mathrm{cm}$ were recorded in the months of August 2002, August
2003 and June 2003 respectively (Table 1). The lower mean values of conductivity observed in the rainy season $(413.67 \mathrm{~ms} / \mathrm{cm})$ when compared with dry season value $(1229.5 \mathrm{~ms} / \mathrm{cm})$, had been attributed to the dilution effect of rains. These values are within the acceptable standard limits of 300 $\mathrm{ms} / \mathrm{cm}(20,16)$. Total suspended solids (TSS), total dissolved solids (TDS) and dissolved oxygen (DO) were higher in dry season than in rainy season. This is due to the dilution effect of rainy and reduced mining activities during the rainy season. The TSS was relatively good since its concentrations were within the minimum acceptable standard for domestic use and many industrial purposes. The value of TDS was however above the permissible international standard of $500 \mathrm{ppm}$. This is objectionable since water higher in dissolved solids should be viewed as potentially corrosive to well screens and other parts of well structure (21). The low range of DO (1.2-3.20 ppm) recorded during the study is an indication that the underground water of Crush Rock mining is not suitable for aquatic life. This is because under favorable environmental conditions, a minimum constant value of $5 \mathrm{ppm}$ (DO), is satisfactory for sustenance of aquatic biota including fishes $(15,22)$. The total alkalinity reported in terms of their equivalent carbonate had range values of $200.18-615.55$ ppm, with higher mean value of $349.83 \mathrm{ppm}$ in dry season and lower value of 234.25 in rainy season. The total alkalinity concentrations exceeded the WHO standard throughout the sampling period. The concentrations of some parameters such as potassium, sulphate and chloride were found to be within the minimum acceptable and maximum allowable WHO standards for drinking and domestic purposes. Nduji et al. reported that chloride, sulphate and nitrate ion content of Nigerian surface and underground waters are negligible when compared with WHO standard (23). Other researchers made similar findings (11, $15,16,24,25)$.

Concentrations of calcium and sodium were found to be well above the maximum acceptable WHO limit. The high values of calcium and sodium recorded may be attributed to the partial solubility of the calcium carbonate $\left(\mathrm{CaCO}_{3}\right)$ and other minerals that are component of the quarry stone $(11,26)$. This observation agrees with earlier findings of this work on increased level of alkalinity since carbonate had been known and 
Underground water quality of rock mining in Ishiagu, Ebonyi state, Nigeria

reported to increase alkalinity (27). There is no reliable standard for silica content in drinking water, however, the silica values of the samples ranged from $2.120-3.590 \mathrm{ppm}$. Higher values of silica had been reported and were attributed to the silty nature of the soil or blasting activities of the rock or probably due to other redox activities $(11,28)$. Resu1ts obtained showed that the rate of accumulation of these heavy meters in the underground water did not vary as such among the samples examined. In all the samples examined, some metals were not detectable. Overall, seasonal variation of these metals shows that rainy season has relatively mean higher values for iron and cadmium than in the dry season. Copper on the other hand had higher mean value in the dry season than rainy season. Lead and Zinc did not display any seasonality thoughout the study. All the values obtained in the present study are however below WHO standard limit (20), FEPA (29) and DPR (30). Although, these trace metals differ widely in their chemical properties, their relative concentrations and discharges and hence, their bioavailability are very important to terrestrial, aquatic and marine organisms in terms of toxicity (31). The emission of these heavy metals often result in extensive and persistent contamination of water and vegetation. The overall effects of the resultant emissions, on the living organisms including animals and humans are many and often life threatening. For example lead is known to produce developmental neurotoxicity and it has been shown that infants, children and pregnant women may be differentially sensitive to environmental lead exposure. Lead can cause abdominal panis, vomiting, drowsiness, convulsion, malfunction of the kidney, reproductive system, liver, brain and the central nervous system structural abnormalities, altered growth and functional deficits, sexual maturity and consequently death $(11,15,32,33,34,35)$. Zinc has low toxicity to man, but relatively high toxicity to fish (36). Thus, contamination of aquatic environments with larger quantities of zinc would cause massive death to fish (37). Although sterile water devoid of microorganisms rarely exist except in the laboratory (38), studies have shown that strategies abound for the treatment of water meant for human consumption to permissible level of microbial flora especially coliform $(14,19,20)$. Thus, the present results suggest that the underground water require further microbiological treatment if the water should be used as drinking water. The results corroborate the levels of microbial flora obtained in other works (11, 15, 26, 39). The presence of Escherichia coli, Pseudomonas sp., Chromobacterium sp. in the water samples is indicative of fecal or related pollution due to either humans or animal (reptiles, birds and rodents) activities. Staphylococcus may have originated from human activities which is indicative of lack of personal hygiene of the miners. There was evidence of indiscriminate defecation and absence of drainage systems in the study area. The surface run off of waters into the mining probably seems to be the major source of the bacterial contamination. Pseudomonas and Bacillus were isolated from the water sample throughout the study and their consistent isolation could be associated with the physiological nature of the organisms usually in water where they can survive with very minimal nutrients as reported by Caincross et al. (40) and Ogbulie and Akujiobi (41). The trend in the isolation of these bacterial species reveals the characteristic microbial contamination of the underground water and the high incidence of some of them in the samples indicate the ability of these organisms to thrive in different environments.

\section{Conclusion}

From the chemical and bacteriological analysis of the underground water, it is evident that the underground water investigated is polluted as compared with standards. Therefore, it is not portable. The pollution level of the underground water is due to the mining activities, human and animals (reptiles, birds, and rodents) activities, water run off and improper refuse and sewage disposal around the mining area.

It is suggested that the state, local government, ministries or agencies responsible for the environmental health, minerals, labour etc. should make and enforce laws on mining, sewage and refuse disposal. Adequate drainage system should be provided to protect the pit and minimize the pollution of the water. It is strongly recommended that these waters should be treated before being used for drinking and other domestic purposes. 


\section{References}

1. Ogbeibu AE, Oribhabor BJ. The Ecological impact of stream regulation using benthic macroinvertebrates as indicators. Journal of Aquatic Sciences 2001; 16(2):132-138.

2. Boyd C. Water quality management for pond fish culture. New York: Elsevier Science Publishers;. 1982. p. 318.

3. Nwigwe HC, Ogoke GO. The effects of paper industry effluent on the physico-chemical qualities and benthic macro-invertebrate community of Nwariegbu stream, South Eastern Nigeria. Journal of Science, Engineering and Technology 2006; 13(1):6609-6618.

4. WHO. Why saving the environmental will be the next century's biggest challenges: In Time WHO Special edition. 1997; 155(15A):14-52.

5. Ruiro MP. An International problem for fisheries. Rome: FAD Fisheries Division; 1971. p. 43.

6. Klein L. River pollution III, Control. London: Butterworths and Co; 1969. p.438.

7. Department of Environment, London River Pollution Survey of England and Wales. London: Public HMSO; 1970. p. 10-25.

8. Marjanovic P, Milorador M, Cikic Z, Boadanovic $\mathrm{S}$, Sakulski D. Integrate cadastre (Inventory system) for pollution sources in the Danube Basin in Yugoslavia. Water Sci and Technology 1995; 32(5-6):265-275.

9. Hatch Manual of Laboratory Turbidimeter. Hatch Chemical Company Houston; 1973. p.5.

10. Philips Manual of Laboratory Conductivity Meter PW /9501/01; 1977 . p. 8.

11. Obiekezie,SO. Effects of mining activities on physico-chemical and bacteriological qualities of water and soil in Ishiagu Area of Ebonyi State, Nigeria. Ph.D Thesis. Abia State University; Uturu, Nigeria: 2005. p. 241.

12. APHA, Standard Methods for Examination of Water and Waste Water. 15th Ed. Washington D.C., USA: APHAM IWPCF; 1980.

13. Hach Water Analysis Handbook.; USA: Hach Coy. Inc; 1981.
14. World Health Organisation. Guidelines for drinking water Quality Geneva; 1982.

15. Abara PN, Obiekezie SO, Onyeagba EA, Nwaugo VO. Physicochemical characteristics of Ivo River, Ebonyi State, Nigeria, International Journal of Natural and applied Sciences 2005; 1(2):145-149.

16. Obasi EA, Balogun O, Ajayi O. The physicochemical investigation of River lreje in Ekiti State SouthWest Nigeria. Journal of Applied Sciences 2004; 7(2):4124-4134.

17. Ozoh PTE, Jones NV. Capacity adaptation of Hediste_(Nereis) diversicolor_Embryogenesis to Salinity, temperature, and copper. Mar Environ Res 1990; 29:227-243.

18. Crawshaw Ll. Physiological and behavioural reactions of fishes to temperature change. Journal of Fish Resource Board Canada 1977; 34:730-736.

19. World Health Organization. International Standards for Drinking Water. 3rd ed. Geneva: WHO; 1971.

20. World Health Organization, Guideline for drinking water quality: Health criteria and supporting information. $2^{\text {nd }}$ ed. Geneva: World Health Organization; 1996.

21. Ross EM. Microbiology for sanitary engineers. New York: McGraw-Hill Book; 1962. p. 151159.

22. Lloyd R, Swift DT. Some physiological responses by fresh fish to low dissolved oxygen, high carbon dioxide, ammonia and phenol with particular reference to water balance. In: Effects of pollutants on aquatic organisms. Lockwood J (ed). Cambridge: Cambridge Univ Press Cambridge; 1976. p. 47-71.

23. Nduji CO, Onwumelu CO, Ekwueme MN, Nwigwe LR. Alternative source of portable water for Enugu Metropolis. Journal of Creativity in Teaching for the Acquisition and Dissemination of Effective Learning 1998; 3(6):42-47.

24. Obiekezie SO. Geochemical investigation of spring waters in parts of Anambra State. Nigeria. Nigeria: Nnamdi Azikiwe University Awka; 1993. p. 93. (Unpublished MScThesis). 
25. Ajiwe VIE, Ogbuagu JO, Njoku OO. The pollution of some Rivers in Igala Area, Kogi State, Nigeria. Journal of Science, Engineering and Technology 1998; 5(2):1142-1150.

26. Nwaugo VO. Aspects of the epidemiology of urinary schistosomiasis and bionomics' of the snail intermediate hosts of Schistosoma, haematobium in quarry pits of Umuchieze. Abia State. Ph.D Thesis. Uturu, Nigeria: Abia State University; 1998. p. 188.

27. Abowei MFN. Production and Consequences of petroleum spills into the Nigerian aquatic environment in the year 2000. International Journal of Environment and pollution 1996; 6(2):206-321.

28. McNeely RN, Neimanis VP, Dwyer L. Silica. In: Water quality source book: A guide to water quality parameters. Water quality Branch, Inland Waters Directorate, Environmental Canada: Ottawa; 1979. p. 51-52.

29. Federal Environmental Protection Agency. Guidelines and standards for environmental pollution control in Nigeria. Government Notives, Federal Republic of Nigeria; 1991. p. 238.

30. Department of Petroleum Resources. Guidelines and standards for environmental pollution control in Nigeria. Nigeria National Petroleum Corporation (NNPC); 1991.

31. Alloway BJ, Ayres DZ. Chemical Principles of Environmental pollution. $2^{\text {nd }}$. London: Blaskie Academic \& Professional; 1997.

32. Johnson BL. Hazardous Waste: Human Health Effects. Toxicol Ind Health 1997; 13(2-3):121143.

33. Goldsmith E, Hildyard N. The earth report: The essential guide to global ecological issues. Los Angeles, California: Prices Sterm Sloan; 1988. p.173.
34. Obiekezie SO. Heavy metal pollution of Ivo River Ishiagu in Ivo Local Government Area of Ebony State. Journal of Science, Engineering and Technology 2006; 13(2):6892-6896.

35. Kanu I, Achi OK, Ezeronye OU, Anyanwu EC. Seasonal variation in bacterial heavy metal biosorption in water samples from Eziama river near soap and brewery industries and the environmental health implications. International Journal of Environmental Science and Technology 2006; 3(1):95-102.

36. Ebong GA, Ita BN, Nyong AB, Benson NU. Seasonal changes in the water quality of Qua Iboe River estuary and its associated creeks in lbeno, Nigeria. Journal of App Sciences 2006; $9(2):$ 6469-6482.

37. Alabasler JS, Llyd R. Water Quality Criteria for fish. 2.nd. London; 1980.

38. APHA. Standard methods for the examination of water and waste water. Washington DC: American Public Health Association; 1998.

39. Obiekezi SO. Assessment of the bacterial organisms in water from a lead-zinc mining pit in Ishiagu, Ebonyi State, Nigeria. International Journal of National and Applied Sciences 2006; 2(1):29-33.

40. Caincross S, Crarruthers I, Crutis D, Feachem R, Brandly D, Baldwing G. Health: Evaluation of village water supply planning. Toronto: John Willey and Sons New York; 1980. p. 74-105.

41. Ogbulie TE, Akujiobi TC. Bacteriological quality of some bottle water sold in Imo State Nigeria. International Journal of National and Applied Sciences 2006; 2(2):122-128.

Recebido em / Received: January 12, 2006. Aceito em / Accepted: February 28, 2006. 